\title{
Diesel exhaust particle exposure in vitro impacts T lymphocyte phenotype and function
}

\author{
Marina Pierdominici ${ }^{1 \dagger}$, Angela Maselli ${ }^{1 \dagger}$, Serena Cecchetti ${ }^{1}$, Antonella Tinari ${ }^{2}$, Arianna Mastrofrancesco ${ }^{3}$, \\ Michela Alfè , Valentina Gargiulo ${ }^{4}$, Carlo Beatrice ${ }^{5}$, Gabriele Di Blasio ${ }^{5}$, Giulia Carpinelli', Elena Ortona ${ }^{1,6}$, \\ Antonello Giovannetti ${ }^{7}$ and Silvana Fiorito ${ }^{7,8,9^{*}}$
}

\begin{abstract}
Background: Diesel exhaust particles (DEP) are major constituents of ambient air pollution and their adverse health effect is an area of intensive investigations. With respect to the immune system, DEP have attracted significant research attention as a factor that could influence allergic diseases interfering with cytokine production and chemokine expression. With this exception, scant data are available on the impact of DEP on lymphocyte homeostasis. Here, the effects of nanoparticles from Euro 4 (E4) and Euro 5 (E5) light duty diesel engines on the phenotype and function of T lymphocytes from healthy donors were evaluated.

Methods: T lymphocytes were isolated from peripheral blood obtained from healthy volunteers and subsequently stimulated with different concentration (from 0.15 to $60 \mu \mathrm{g} / \mathrm{ml}$ ) and at different time points (from $24 \mathrm{~h}$ to 9 days) of either E4 or E5 particles. Immunological parameters, including apoptosis, autophagy, proliferation levels, mitochondrial function, expression of activation markers and cytokine production were evaluated by cellular and molecular analyses.

Results: DEP exposure caused a pronounced autophagic-lysosomal blockade, thus interfering with a key mechanism involved in the maintaining of T cell homeostasis. Moreover, DEP decreased mitochondrial membrane potential but, unexpectedly, this effect did not result in changes of the apoptosis and/or necrosis levels, as well as of intracellular content of adenosine triphosphate (ATP). Finally, a down-regulation of the expression of the alpha chain of the interleukin (IL)-2 receptor (i.e., the CD25 molecule) as well as an abnormal Th1 cytokine expression profile (i.e., a decrease of IL-2 and interferon (IFN)- $\gamma$ production) were observed after DEP exposure. No differences between the two compounds were detected in all studied parameters.
\end{abstract}

Conclusions: Overall, our data identify functional and phenotypic T lymphocyte parameters as relevant targets for DEP cytotoxicity, whose impairment could be detrimental, at least in the long run, for human health, favouring the development or the progression of diseases such as autoimmunity and cancer.

Keywords: Air pollution, DEP, T lymphocytes, Autophagy, Mitochondria, IL-2

\section{Background}

Particulate matter in air pollution is associated with adverse health effects such as asthma and cardiovascular diseases as well as lung cancer mortality [1-4]. Diesel exhaust particles (DEP) emitted by diesel engines consist of fine particles (particulate matter with an aerodynamic diameter $\leq 2.5 \mu \mathrm{m}$ ) including a high number of ultrafine

\footnotetext{
* Correspondence: silvana.fiorito@uniroma1.it

${ }^{\dagger}$ Equal contributors

${ }^{7}$ Department of Clinical Medicine, Division of Clinical Immunology, Sapienza University of Rome, Rome, Italy

${ }^{8}$ Institute of Translational Pharmacology, CNR-Rome, Italy

Full list of author information is available at the end of the article
}

particles $(<0.1 \mu \mathrm{m}$ diameter). They are composed of a center core of elemental carbon (80\%) and adsorbed organic compounds, including polycyclic aromatic hydrocarbons (PAH) and nitro-PAH, and small amounts of sulfate, nitrate, metals, and other trace elements. All these compounds are considered to be of great toxicological importance. The small size of DEP makes them highly respirable, thus having the potential to reach the deep lung and to translocate to the bloodstream although this latter still remains a debated issue [2,5-10]. In particular, it has been suggested that ultrafine carbon particles, after deposition in the lung, largely escape 
alveolar macrophage surveillance and gain access to the pulmonary interstitium. From this site, a further translocation of the ultrafine particles to the blood circulation via lymphatic channels or directly via the endothelium could take place $[8,9]$.

A series of studies in vivo revealed that DEP exposure has remarkable effects on the immune system: pre- and postnatal animal exposures to DEP decrease the weight of the thymus and spleen, accelerate the production of IgE against pollen, increase allergic susceptibility, alter inflammatory indices in the lung, and increase airway hyperesponsiveness [11,12]. These findings in animal models have been partially confirmed in in vitro and in vivo human studies, and the largest literature in this regard has looked at the link between DEP exposure and allergic diseases. In fact, it has been demonstrated that DEP exposure can both exacerbate existing allergic diseases and cause allergic sensitization by promoting a Th2 cytokine profile [12-24]. The precise mechanism by which DEP exposure promotes allergic responses is not entirely clear, although oxidant activity of the adsorbed PAH, rather than properties specific to the carbon core, appears to be involved. With the exception of these studies regarding cytokine production, scant data are available on the impact of DEP on lymphocyte phenotype and function. This topic has substantial importance in light of evidence that aberrant lymphocyte homeostasis can result in several diseases including autoimmune, allergic and even neoplastic diseases. In one study, chronic in vitro exposure of $\mathrm{T}$ lymphocytes to DEP-PHA increased $\mathrm{T}$ cell activation marker expression and proliferation in asthmatics but not in controls [19]. More recently, Vattanasit et al. [25] demonstrated that reactive oxygen species generation and oxidative DNA damage were induced by DEP in both lymphoblasts and lung cells suggesting that lymphocytes could be used as a surrogate to assess DEP-dependent responses in the lung. No data are currently available on the effects of DEP on T cell fate in terms of apoptosis or autophagy. This latter is a lysosome-mediated catabolic process that allows cells to degrade unwanted cytoplasmic constituents and recycle nutrients [26], and it has been recently emerged as a key parameter, in addition to apoptosis [27], in the maintaining of lymphocyte homeostasis [28-31].

In the last years, all major automobile companies, in order to decrease the dangerous effects of the environmental pollution deriving from DEP on human health, produced and put into the market diesel engines at lower particle emission rate than in the past as well as filters for soot particles. Nevertheless, these strategies neglected the question of how soot quality, more than quantity, may change its effect on human health. Our previous findings demonstrated that carbon based nanoparticles from a low emission diesel engine (Euro 4, E4) are more toxic against human macrophage and skin cells than the older diesel engine black soot (BS), highlighting how low-emission engine soot has a higher toxic potential per unit mass than the soot produced from an older engine [32,33]. In the present study, the impact of nanoparticles from $\mathrm{E} 4$ and Euro 5 (E5) light duty diesel engines on the phenotype and function of circulating $\mathrm{T}$ lymphocytes from healthy donors was evaluated in order to assess whether environmental nanoparticulate is able to interfere with $\mathrm{T}$ cell homeostasis, thus favouring, at least on a susceptible background, the development of disorders associated with abnormal lymphocyte homeostasis. To this aim, different immunological parameters including apoptosis, autophagy, proliferation levels, mitochondrial function, expression of activation markers and cytokine production were evaluated.

\section{Results}

\section{E4 and E5 chemical-physical features}

A detailed chemical and structural characterization of E4 and E5 soot was reported previously [34]. Briefly, E5 soot aerodynamic diameter, measured by a differential mobility spectrometer (DMS), was observed to be slightly larger $(90 \pm 5 \mathrm{~nm})$ than that of $E 4$ soot $(80 \pm 5 \mathrm{~nm})$. This finding was confirmed by the evaluation of the hydrodynamic diameter measured using dynamic light scattering (DLS, $115 \pm 5 \mathrm{~nm}$ and $95 \pm 5 \mathrm{~nm}$, for E5 and E4 respectively). Both E4 and E5 soots consisted of irregularly shaped compact aggregates of almost spherical primary particles $(15-20 \mathrm{~nm})$. Infrared and UV-vis absorption spectroscopy indicated that the samples exhibited predominantly sp2-hybridization, indicative of the presence of highly conjugated systems [35]. The highly conjugated systems (graphene layers) were tightly connected each other in a compact aggregate constituting the center core of elemental carbon with well-defined morphological features, as imaged by high resolution transmission electron microscopy (HRTEM). The soot was pretreated (as described in soot sampling and pre-treatment paragraph) in order to remove all non-covalently bound molecules adsorbed on its surface. The presence of oxygen functional groups (mainly $\mathrm{C}=\mathrm{O}$ ) was also detected. Although E4 and E5 soots appeared quite similar in terms of surface functionalities, the graphitization degree was slightly more pronounced in the E5 soot (73\%), indicating a lower presence of defective sites (bent graphene layers, oxygenated sites) with respect to E4 soot (69\%). Even though non-specific interactions (i.e., hydrophobic, van der Waals interactions) arose between the particles when sampled on the filter, nano- and micro-structures (primary particles dimension, aggregate size, particle size distribution) and surface chemical-physical properties resulted unaffected. As concerns the size distribution of the particles, a powerful solvent as N-metyl pirrolidinone (NMP) was able to disperse 
the particles in a colloidal stable suspension demonstrating the non-covalent nature of the soot aggregates [35,36]. Moreover, DLS performed on NMP soot suspensions demonstrated that the aggregate diameter of the soot particles was comparable to that measured on-line by DMS. A 5-10 wt.\% of stable residual was detected for both E4 and E5 soots by termogravimetric analysis (TGA) and indicated the presence of inorganic impurities (additives to the lubricating oil or to the diesel fuel itself, engine wear).

\section{Exposure to DEP did not affect T cell apoptosis or necrosis} In order to assess the intracellular localization of nanoparticulate in lymphocytes, a transmission electron microscopy (TEM) analysis was carried out. Agglomerates of nanoparticles were found to be incorporated into membrane-bound vacuoles in the cytoplasmic region (Figure 1A: E4, left panel and E5, right panel). No agglomerates of nanoparticles were observed free in the cytoplasm or in the nucleus. No ultrastructural features of cell death, e.g., apoptosis, were detected. Possible changes of apoptosis and/or necrosis levels in response to DEP treatment were further evaluated by using a dual staining with annexin $\mathrm{V}(\mathrm{AV})$, a cell surface marker for apoptotic cells and propidium iodide (PI), a DNA intercalating agent which only enters cells that have lost membrane integrity. This assay enables identification of both early (AV positive/PI negative) and late apoptotic or necrotic cells (PI positive). No significant effects on these parameters were observed in $\mathrm{T}$ lymphocytes in response to E4 or E5 particles used in the concentration range from 0.15 to $60 \mu \mathrm{g} / \mathrm{ml}$ and at different time-points (i.e., from $24 \mathrm{~h}$ to 9 days). Results of dose-response experiments performed at $48 \mathrm{~h}$ are shown in Figure 1B.

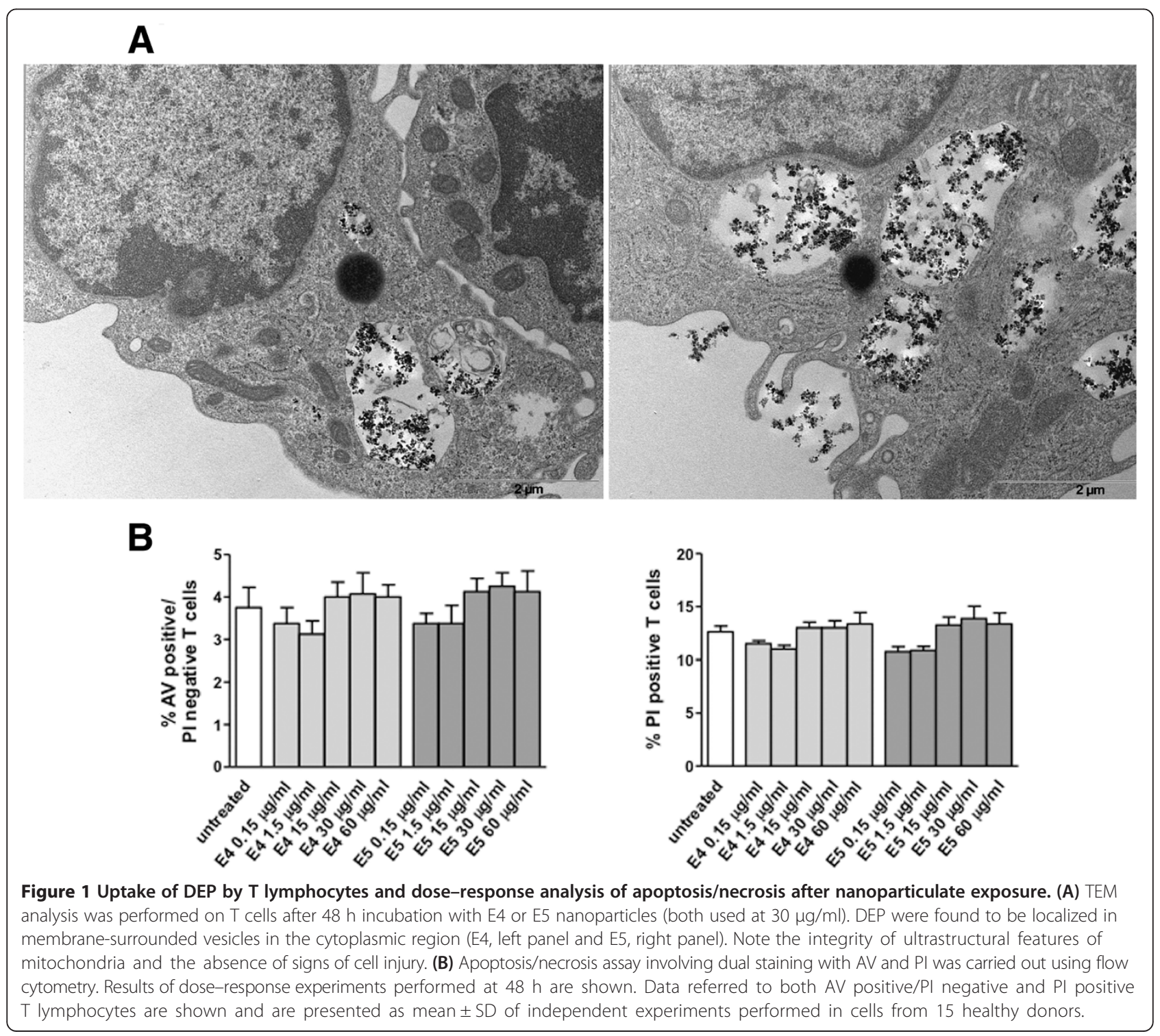


Notably, after 6 and 9 days of culture, a reduction of PI positive $\mathrm{T}$ lymphocytes, although not significant $(\mathrm{p}>0.05)$, was detected after DEP treatment (see Additional file 1: Figure S1). At these time points, no changes were observed in treated versus untreated cells within the AV positive/PI negative $\mathrm{T}$ cell population.

\section{Exposure to DEP induced autophagic blockade in T lymphocytes}

Autophagy is detectable in human $\mathrm{T}$ lymphocytes and a complex function for it in T lymphocyte development, survival, and proliferation has been recently described [28-31]. During autophagy, portions of cytoplasm are sequestered by double-membrane vesicles, the autophagosomes, and degraded after fusion with lysosomes for subsequent recycling [26]. Here, we investigated whether exposure to DEP could modify the autophagy level in $\mathrm{T}$ lymphocytes measuring by Western blot the expression of an established set of autophagosomal markers: microtubule-associated protein 1 light chain 3 (LC3), sequestosome 1 (SQSTM1), neighbor of BRCA1 gene 1 (NBR1), and $\alpha$-synuclein (SNCA) [37,38]. LC3 (Atg8 in the yeast) is an essential factor for autophagosome formation [39]. Its unlipidated cytosolic form is called LC3-I, whereas the lipidated form is referred as to LC3-II and localizes to autophagosomal membranes throughout the maturation process of the autophagosome. For this reason, LC3-II is commonly used as a specific marker for monitoring autophagy levels [38]. A dose-dependent and timedependent accumulation of LC3-II occurred in response to treatment with both E4 and E5 particles and a significant increase was observed after $24 \mathrm{~h}$ of culture at concentrations starting from $15 \mu \mathrm{g} / \mathrm{ml}$. Results of dose-response experiments performed at $48 \mathrm{~h}$ are shown in Figure 2A. Additionally, a significant accumulation of SQSTM1 and NBR1, substrates that undergo depletion upon autophagy induction [38], was detected (Figure 2B). A similar increase occurred with SNCA (Figure 2B), which is another autophagic substrate protein that accumulates as a consequence of the blockade of autophagic lysosomal flux [37]. Note that in these and the subsequent experiments E4 and E5 particles were used at a concentration of $30 \mu \mathrm{g} / \mathrm{ml}$ for $24 \mathrm{~h}-72 \mathrm{~h}$ (depending on the studied parameter) on the basis of preliminary dose-response and time-course experiments (see Methods and Additional file 1: Figure S1, for details). In order to gain further insight into the mechanism of DEP-induced autophagic alterations, a LC3 turnover assay, employing the lysosomal inhibitors E64d and pepstatin A (PepA) co-treatment, was performed (Figure 2C). In fact, it is well known that LC3-II can accumulate because of increased upstream autophagosome formation or impaired downstream autophagosome lysosome fusion [38]. To distinguish between these two possibilities, we assayed DEP-induced LC3-II accumulation in the presence or absence of the above mentioned lysosomal protease inhibitors. As observed above, DEP treatment caused an increase of LC3-II levels and, importantly, when DEP exposure occurred in the presence of E64d and PepA, DEP-induced upregulation of LC3-II levels was not potentiated, this being consistent with an autophagiclysosomal blockade of LC3-II degradation at the autolysosomal level. Previous results by our group [32,33] showed that E4 particles possessed a higher cytotoxic potential as compared to BS particles. Therefore, to compare these compounds in terms of autophagy modulation, we performed the above described set of experiments on BS-treated T lymphocytes. We found that BS induced an autophagic blockade similarly to that observed with E4 and E5 compounds (see Additional file 1: Figure S2).

\section{Exposure to DEP affected mitochondrial membrane potential $(\Delta \Psi \mathrm{m})$}

Mitochondria play a primary role in cell physiology, providing the energy supply to the cells as well as controlling their fate [40]. We further characterized DEP cytotoxicity in term of mitochondrial function. To this aim, we first analyzed changes of $\Delta \Psi \mathrm{m}$ in DEP-treated $\mathrm{T}$ lymphocytes. Quantitative flow cytometry analysis, performed using the 5,5',6,6'-tetrachloro-1,1',3,3' -tetraethylbenzimidazol carbocyanine iodide (JC-1) probe, showed that both E4 and E5 particles induced a significant loss of $\Delta \Psi \mathrm{m}$ already detectable after $24 \mathrm{~h}$ of treatment $(26 \pm 4 \%$ and $25 \pm 3 \%$ respectively versus $11 \pm 3 \%$ of untreated cells, Figure $3 \mathrm{~A}, \mathrm{~B}$ ). The difference between treated and untreated cells was no longer significant starting from $72 \mathrm{~h}$. To note, loss of $\Delta \Psi \mathrm{m}$ was not followed by an increase in the percentage of apoptotic/necrotic cells that remained unchanged in treated versus untreated cells (see above). Because $\Delta \Psi \mathrm{m}$ is the driving force for mitochondrial ATP synthesis and loss of $\Delta \Psi \mathrm{m}$ may result in depletion of cellular adenosine triphosphate (ATP) level [41], we also measured the ATP content in E4- and E5-treated T lymphocytes. We did not detect any change of this parameter after cell treatment (Figure 3C).

\section{Exposure to DEP significantly reduced the expression of CD25 molecule but did not interfere with the expression of other $\mathrm{T}$ cell activation markers or with proliferation level}

Next, we examined the possible effects of DEP on the activation state of $\mathrm{T}$ lymphocytes as well as on their proliferation rate. To this aim, the expression of activation markers (CD69, CD25, HLA-DR and CD95 molecules) was evaluated in $\mathrm{CD}_{4}^{+}$and $\mathrm{CD}^{+} \mathrm{T}$ lymphocytes. The expression of CD25 molecule was down-regulated on $\mathrm{CD}_{4}^{+}$, but not on $\mathrm{CD}^{+}, \mathrm{T}$ cells in response to both E4 and E5 treatments from $24 \mathrm{~h}$ to $72 \mathrm{~h}$ of cell culture (nadir at $48 \mathrm{~h}, \mathrm{p}=0.0025$ and $\mathrm{p}=0.0018$ for E4- and E5-treated cells versus untreated cells, respectively, Figure 4A) whereas starting 
A
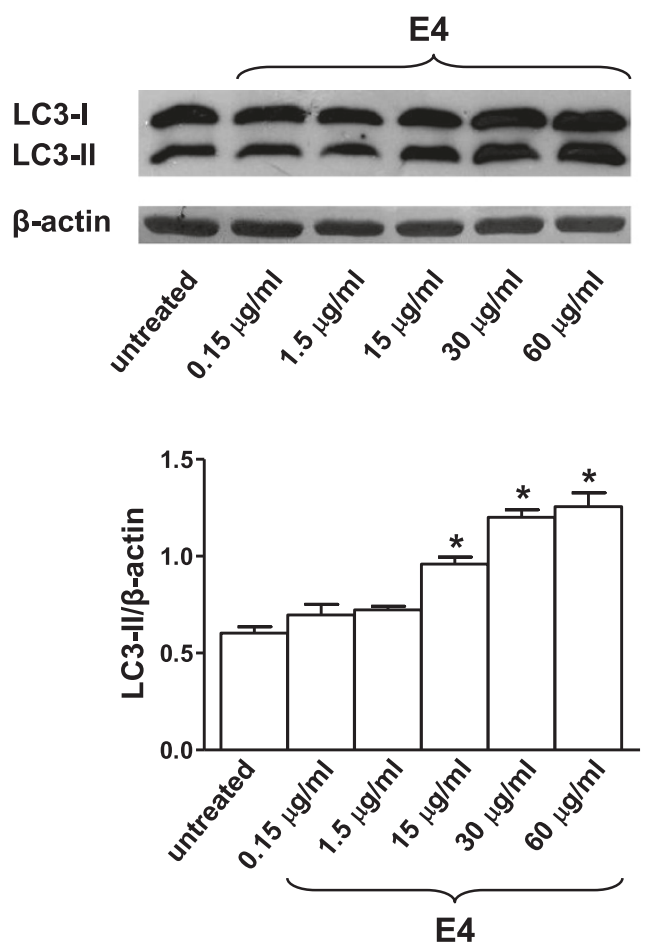
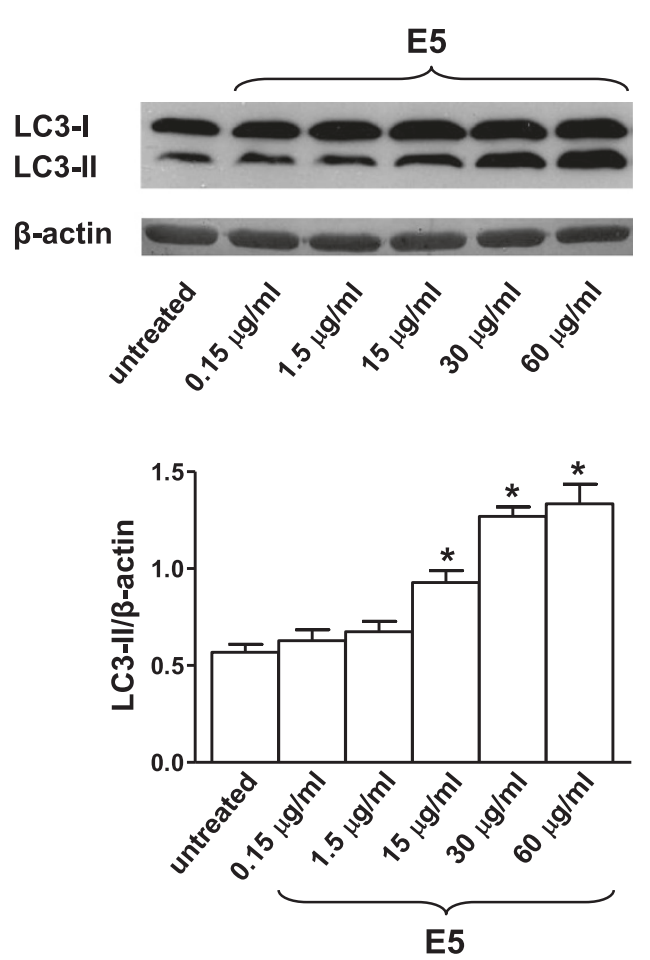

B
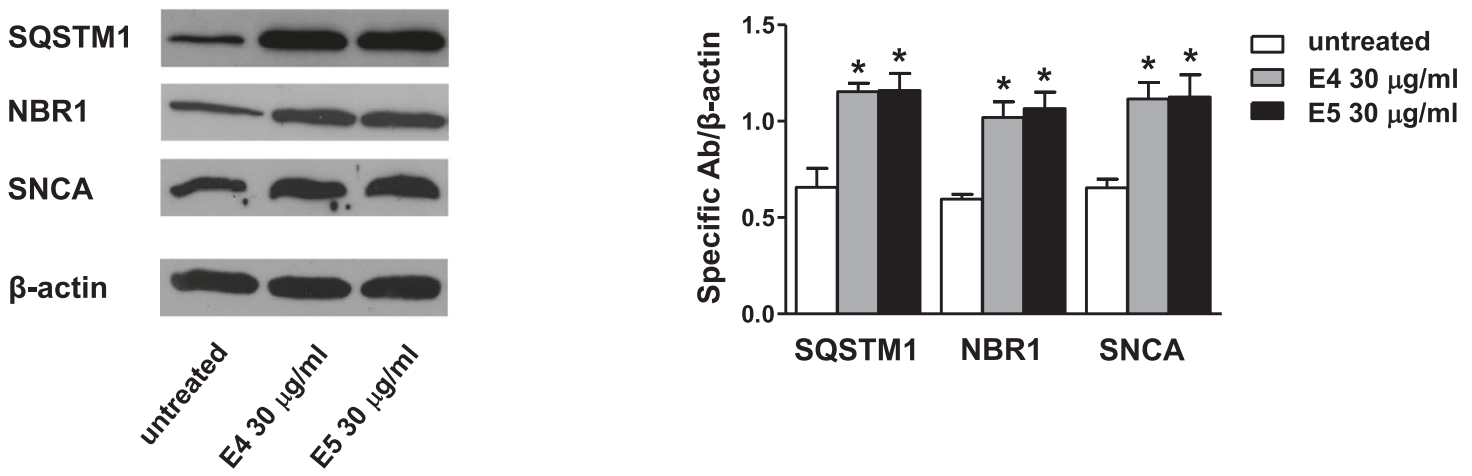

C

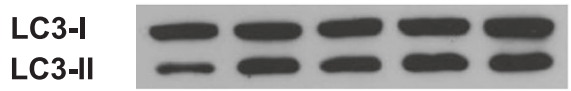

$\beta$-actin
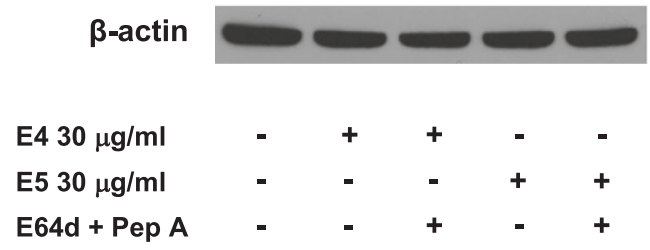

Figure $\mathbf{2}$ (See legend on next page.)

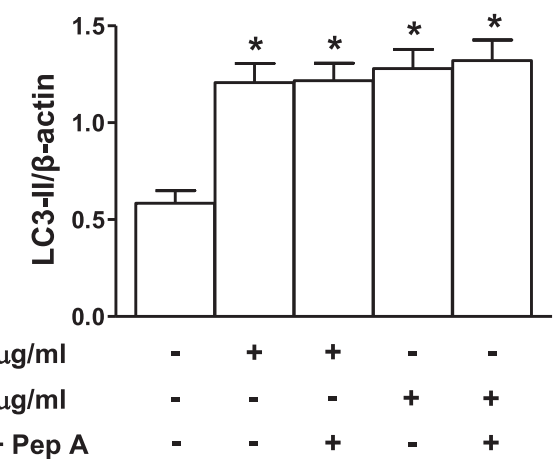


(See figure on previous page.)

Figure 2 DEP-induced autophagic-lysosomal blockade in human T lymphocytes. (A) LC3-II Western blot analysis of T-cell lysates (30 $\mu \mathrm{g} / \mathrm{lane})$ from one representative healthy donor (of the 15 analyzed) after treatment with different concentrations $(0.15-60 \mu \mathrm{g} / \mathrm{ml}$ for $48 \mathrm{~h}$ ) of E4 or E5 particles. Densitometry analysis of LC3-II levels relative to $\beta$-actin is also shown. Values are expressed as mean \pm SD obtained from independent experiments performed in cells from 15 healthy donors. Statistically significant differences are indicated in the figure. ${ }^{*} p<0.05$ versus untreated cells. (B) Western blot analysis of autophagic-lysosomal proteins (SQSTM1, NBR1, SNCA) in T-cell lysates from one representative healthy donor (of the 15 analyzed) after treatment with E4 or E5 $(30 \mu \mathrm{g} / \mathrm{ml}$ for $48 \mathrm{~h}$ ) particles. Densitometry analysis of specific protein levels relative to $\beta$-actin is also shown. Values are expressed as mean \pm SD obtained from independent experiments performed in cells from 15 healthy donors. Statistically significant differences are indicated in the figure. ${ }^{*} p<0.05$ versus untreated cells. (C) LC3-II Western blot analysis of T-cell lysates from one representative healthy donor (of the 15 analyzed) after treatment with E4 or E5 $(30 \mu \mathrm{g} / \mathrm{ml}$ for $48 \mathrm{~h})$ particles in the absence or presence of the lysosomal inhibitors E64d and pepstatin A. Densitometry analysis of LC3-II levels relative to $\beta$-actin is also shown. Values are expressed as mean \pm SD obtained from independent experiments performed in cells from 15 healthy donors. Statistically significant differences are indicated in the figure. ${ }^{*} p<0.05$ versus untreated cells. SQSTM1, sequestosome 1; NBR1, neighbor of BRCA1 gene 1; SNCA, a-synuclein; Pep A, pepstatin A.

from day 6 no differences between untreated and treated cells were detected. Conversely, in the same experimental condition, no changes in the expression of CD69, HLA-DR and CD95 molecules were detected in both $\mathrm{CD}^{+}$and $\mathrm{CD}^{+} \mathrm{T}$ cells (Figure 4A). The effect of exposure to DEP was also evaluated in terms of modulation of $\mathrm{T}$ cell proliferation. Both resting and anti-CD3-activated
T lymphocytes were treated with E4 or E5 particles and the rate of cell proliferation was detected by measuring the Ki-67 nuclear Ag expression. For T cell activation, both suboptimal $(1.25 \mu \mathrm{g} / \mathrm{ml})$ and optimal (2.5 $\mathrm{\mu g} / \mathrm{ml})$ concentrations of anti-CD3 monoclonal antibody (mAb) were used. As shown in Table 1, exposure to E4 or E5 particles did not have any effect
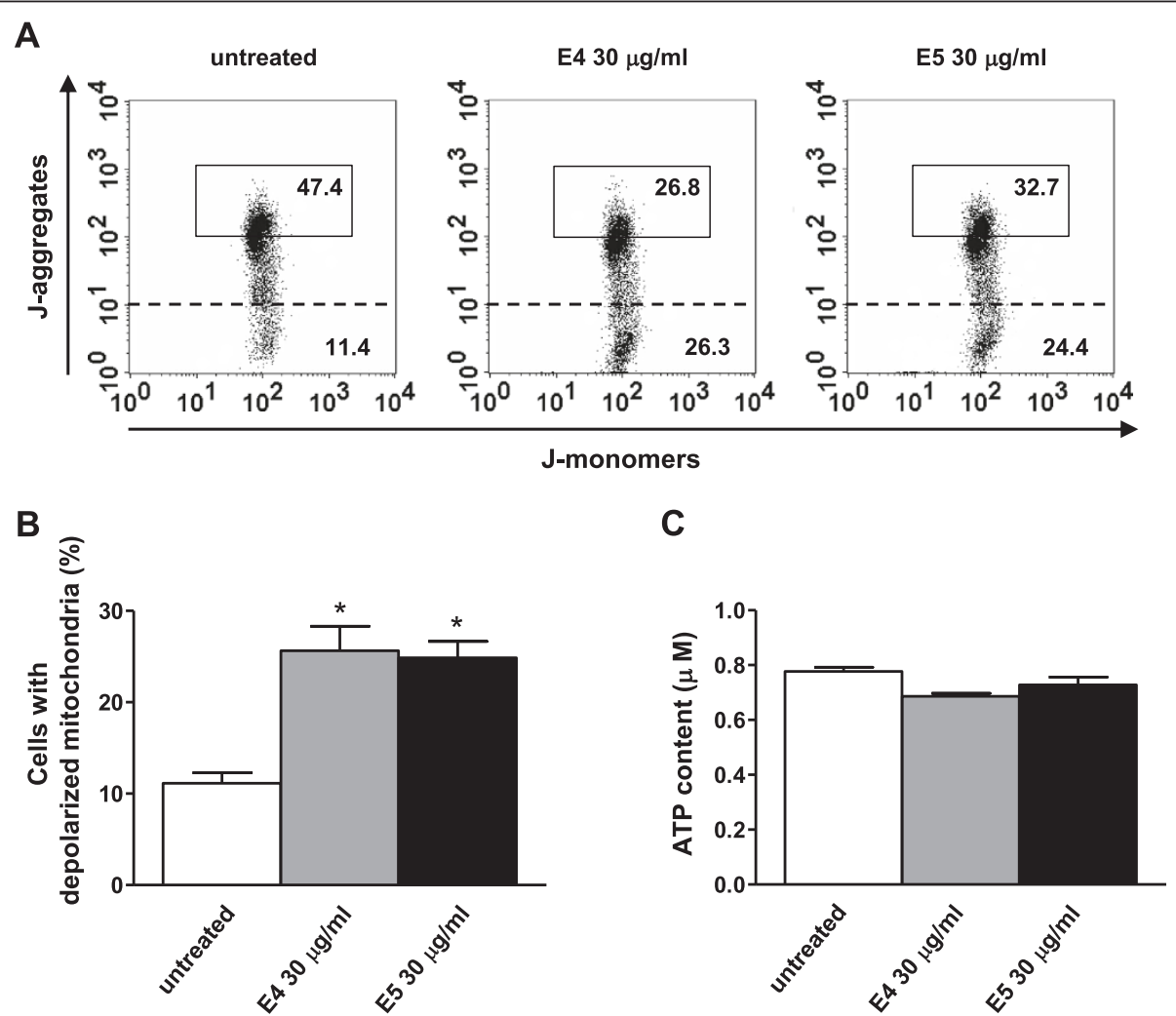

Figure 3 Loss of $\Delta \Psi_{\mathrm{m}}$ but preserved ATP content after exposure of T lymphocytes to DEP. (A) Flow cytometry analysis of $\Delta \psi_{\mathrm{m}}$ after staining with $\mathrm{JC}-1$ in untreated T lymphocytes (left panel), T lymphocytes treated with E4 (middle panel) or E5 (right panel) particles ( $30 \mathrm{\mu g} / \mathrm{ml}$ for $24 \mathrm{~h}$ for both compounds). The results obtained in a representative experiment are shown. The numbers in the boxed areas represent the percentages of cells with hyperpolarized mitochondria. The percentages of cells with depolarized mitochondria are shown below the dashed line. (B) Mean percentage (and SD) of lymphocytes with depolarized mitochondria obtained from independent experiments performed in cells from 15 healthy donors is also shown. ${ }^{*} p<0.05$ versus untreated cells. (C) ATP content detected by chemiluminescent assay in untreated and E4-and E5-treated T lymphocytes ( $30 \mathrm{\mu g} / \mathrm{ml}$ for $24 \mathrm{~h}$ for both compounds). Data are expressed as mean \pm SD and are obtained from independent experiments performed in T lymphocytes from 5 out 15 randomly selected healthy donors. 


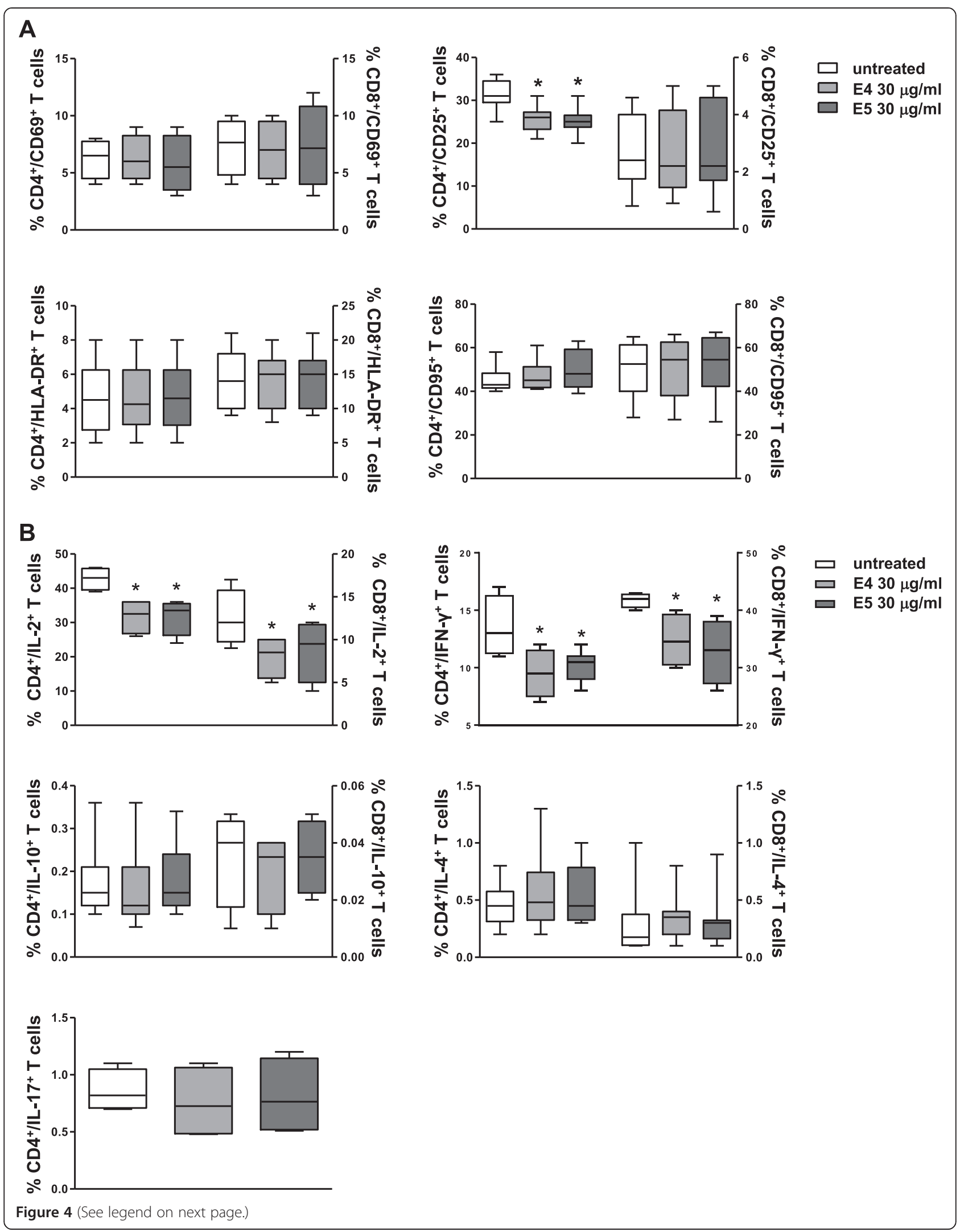


on the level of cell proliferation in both resting and activated $\mathrm{T}$ cells.

\section{Exposure to DEP significantly reduced Th1 cytokine production}

The production of a panel of cytokines, including interleukin (IL)-2, interferon (IFN)- $\gamma$, IL-4, IL-10, and IL-17, was evaluated at the single cell level in $\mathrm{CD}^{+}$and $\mathrm{CD} 8^{+}$ $\mathrm{T}$ cells. Results are summarized in Figure 4B. Exposure to E4 or E5 particles significantly suppressed IL-2 production in $\mathrm{CD}^{+}$and $\mathrm{CD}^{+} \mathrm{T}$ cells without significant differences between the two compounds $\left(\mathrm{CD} 4^{+} \mathrm{T}\right.$ cells, $\mathrm{p}<0.0001$ for both E4- and E5-treated cells versus untreated cells; $\mathrm{CD}^{+} \mathrm{T}$ cells, $\mathrm{p}=0.005$ and $\mathrm{p}=0.034$ for E4- and E5-treated cells versus untreated cells, respectively). Also for IFN- $\gamma$ production, after DEP treatment, a significant reduction was observed with both compounds in $\mathrm{CD}_{4}^{+}(\mathrm{p}=0.003$ and $\mathrm{p}=0.004$ for E4- and E5treated cells versus untreated cells, respectively) and $\mathrm{CD}^{+} \mathrm{T}$ cells $(\mathrm{p}=0.0005$ and $\mathrm{p}=0.0002$ for E4- or E5treated cells versus untreated cells, respectively). Regarding IL-4, IL-10, and IL-17 production no significant changes were found in treated versus untreated cells. In particular, for IL-4 and IL-10 expression level, a great inter-individual variability was detected in response to E4 or E5 particles (Figure 4B).

\section{Discussion}

In this study, we observed that in vitro exposure of human T lymphocytes to E4 and E5 diesel exhaust nanoparticles has a strong impact on their phenotype and function. We focused on the role played by the particle core in order to discriminate its effect (not yet reported in the current literature) from that due to the adsorbed

Table 1 Exposure to DEP did not interfere with T cell proliferation

\begin{tabular}{llll}
\hline & \multicolumn{3}{l}{$\%$ Ki-67 $\mathbf{T}^{+}$T lymphocytes } \\
\cline { 2 - 4 } & Untreated & E4 & E5 \\
\hline Resting T lymphocytes & $0.13 \pm 0.02$ & $0.12 \pm 0.03$ & $0.12 \pm 0.03$ \\
Activated T lymphocytes: & & & \\
anti-CD3 $(2.5 \mu \mathrm{g} / \mathrm{ml})$ & $71 \pm 5$ & $69 \pm 6$ & $67 \pm 5$ \\
anti-CD3 $(1.25 \mu \mathrm{g} / \mathrm{ml})$ & $23 \pm 4$ & $22 \pm 2$ & $21 \pm 3$
\end{tabular}

Data are expressed as mean \pm SD and are obtained from independent experiments performed in T cells from 15 healthy donors after cell treatment with E4 or E5 particles (both used at $30 \mu \mathrm{gg} / \mathrm{ml}$ for $72 \mathrm{~h}$ ) in the presence (activated T lymphocytes) or absence (resting T lymphocytes) of anti-CD3 mAb. species. We also addressed our investigations on the impact of the engine technology level (as the combustion system) on the emitted soot nanoparticles, neglecting the effect of the after-treatment system (diesel oxidation catalyst, DOC, and diesel particulate filter, DPF). It should be noted that although the exhaust after-treatment system changes the physical-chemical features of the raw combustion-formed soot particles, it has been reported that these changes are not dramatic and the nanostructure of the particles that reach the ambient air is strictly correlated to the particles collected upstream the after-treatment system [42].

The efforts of the producers are aimed to further decrease the negative impact on human and animal health of diesel exhaust nanoparticulate reducing particle emission rate as well as introducing filters for soot particles. Since E5 engines emit about a fifth of the E4 engines in terms of mass, their impact, expressed as toxic potential/ kilometer or $/ \mathrm{kWh}$, is lower. However, our results demonstrate that E5 engines present the same toxic potential of E4 engines in terms of soot quality. These results can be related to the very similar structural features exhibited by the two diesel soots. In particular, the species removed from the soot surface by particle processing are chemically similar in both E4 and E5 soots suggesting that no significant differences in toxicological behavior can be forecasted on the unwashed soot.

To our knowledge, this is the first report describing the effect of DEP on T cell fate in terms of apoptosis, necrosis, and autophagy. Although exposure to E4 or E5 particles does not seem to significantly impact apoptosis or necrosis, it influences the autophagy process inducing an autophagic-lysosomal blockade. Interestingly, a similar effect was observed with carbonaceous particulate from an older diesel engine (i.e., BS), thus suggesting comparable toxicity in terms of autophagy dysfunction between this compound and E4/E5 particles. The defect of autophagosome degradation could be consistent with a functional block induced by DEP at the lysosomal level [43]. In this regard, Chaudhuri et al. [44] found that chronic in vitro exposure of monocyte-derived macrophages to concentrations of DEP $\geq 10 \mu \mathrm{g} / \mathrm{ml}$ caused a loss of lysosomal acidification and this could result in an impairment of $\mathrm{pH}$ control and inactivation of lysosomal proteases. On the other hand, lysosomal overload by nanoparticulate has been proposed as a further mechanism for the blockade of autophagy flux [43]. The finding of an autophagy 
impairment induced by DEP reveals a critical mechanism by which nanoparticulate could interfere with lymphocyte homeostasis and immune responses. Basal levels of autophagy contribute to the physiological turnover of proteins and to the removal of old and/or damaged organelles [45]. Autophagy is also involved in innate and adaptive immune responses, playing a key role in interactions against microbes [46], in antigen processing for major histocompatibility complex presentation [47], in lymphocyte development, survival, and proliferation [28]. Importantly, over recent years, defective autophagy has been implicated in a number of diseases [45]. For instance, evidence suggests that autophagy blockade can favour cancer development allowing the accumulation of damaged mitochondria that can induce oxidative stress, inflammation and DNA damage $[48,49]$. Disruption of the autophagy pathway has also been associated with autoimmune disorders such as Systemic Lupus Erythematosus in which autophagy blockade may lead to accumulation of damaged mitochondria, increased production of reactive oxygen species and increased apoptosis, all pathogenetic events in this disease $[29,50]$. In this context, future studies on affected populations, specifically focused to assess a link between nanoparticulate-induced autophagy dysfunctions and disease development and progression, could provide fruitful information.

Here, we observed that DEP-induced autophagy blockade was concomitant with mitochondrial membrane perturbations. DEP-induced mitochondrial membrane alterations, leading to dissipation of $\Delta \Psi \mathrm{m}$, have been demonstrated by different studies [51-53] although the biologic consequences of this effect are far from being fully elucidated. Loss of $\Delta \Psi \mathrm{m}$ generally precedes apoptosis [54] and, consistently with this assumption, rat pulmonary alveolar macrophages or murine macrophage cell lines exposed to DEP show an orderly sequence of events, i.e., collapse of $\Delta \Psi \mathrm{m}$, initiation of apoptosis, uncoupling of oxidative phosphorylation, and decreased ATP production [51,53]. On the other hand, Wang et al. [52] found a loss of $\Delta \Psi \mathrm{m}$ in the absence of apoptosis in different human cells (e.g., THP-1 monocytes, A549 lung epithelial cells and primary red blood cells) exposed to DEP. Similar results were obtained by our group in T lymphocytes, suggesting that diesel nanoparticulate has a property that prompts mitochondria membrane collapse without inducing apoptosis. Reduced $\Delta \Psi \mathrm{m}$ and parallel resistance to apoptosis have been described in the mitochondrial DNA-depleted $\rho^{0}$ cells [55] and a depletion of mitochondrial DNA could be hypothesized after DEP exposure. Further research is underway to investigate this issue. Notably, in our experimental conditions, ATP content remained unchanged after DEP treatment suggesting that compensatory mechanism to produce ATP (e.g., glycolysis) could be activated in $\mathrm{T}$ lymphocytes to produce a sufficient amount of energy and to maintain housekeeping functions avoiding cell death. Interestingly, as stated above, we observed a reduction of apoptotic cells, although not significant, after 6-9 days of culture. The survival of DEP-treated T lymphocytes could be facilitated by the fact that diesel nanoparticulate seems to favour a quiescent phenotype (e.g., down regulation of CD25 expression) with a low energy demand. Actually, a further mechanism by which DEP could interfere with lymphocyte homeostasis is their immunosuppressive activity. Previously reported data by Mamessier et al. [19] showed that DEP-PAH exposure induced the expression of activation markers, including CD25 molecule, on T cells from asthmatic patients but not from controls. Here, we analysed the expression of different cell activation markers separately on $\mathrm{CD} 4^{+}$and $\mathrm{CD} 8^{+}$ $\mathrm{T}$ cells from healthy donors and observed that DEP were able to reduce the expression of the CD25 molecule on $\mathrm{CD}^{+}{ }^{+} \mathrm{T}$ cells. Discrepancies with the data by Mamessier et al. [19] could be explained by the different characteristics of the nanoparticulate used (e.g., PAH content) and by the different methodological approach. In fact, our study focused on the effect of DEP on T cells from healthy donors, while $\mathrm{T}$ cells from patients affected by chronic respiratory diseases, committed by persistent antigen stimulation to a specific immunological profile [56], were the object of the above mentioned study. Notably, we also found a significant reduction of IL-2 production in both $\mathrm{CD}^{+}$and $\mathrm{CD}^{+}{ }^{+} \mathrm{T}$ cells. Interleukin- 2 is the prototypic growth factor for $\mathrm{T}$ lymphocytes and it promotes $\mathrm{T}$ cell survival, proliferation, and differentiation into effector cells [57]. Interleukin-2 also functions to limit immune responses by stimulating the development and functions of regulatory $\mathrm{T}$ cells [58] and by promoting Fas-mediated apoptotic death of $\mathrm{CD}^{+} \mathrm{T}$ cells [59]. Therefore DEP exposure by decreasing IL-2 production could lead to a defective immune surveillance and to an abnormal persistence of activated T cells. The reduction of IFN- $\gamma$ production that we observed after DEP exposure in both $\mathrm{CD}^{+}$and $\mathrm{CD}^{+}{ }^{+} \mathrm{T}$ cells further contributes to the defective Th1 profile. This finding, in association with the recent observation that DEP decrease markers of cytotoxic natural killer cells and functionally suppress cell-mediated cytotoxicity [60], strongly supports the hypothesis that DEP exposure may increase the susceptibility to viral infections.

\section{Conclusions}

Overall, our data identify some functional and phenotypic $T$ lymphocyte parameters as relevant targets for DEP cytotoxicity, whose impairment could be detrimental, at least in the long run, for human health, favouring the development or the progression of diseases such as cancer and autoimmunity. Further studies are now warranted i) to better elucidate the functional endpoints of DEP actions 
highlighted by the current study and ii) to address the impact of exhaust after-treatment system on soot nanoparticles during its normal operation and regeneration phase, by collecting the tailpipe emitted particles that represent more strictly the ambient air particulate.

\section{Methods \\ Particle collection and characterization Experimental set up}

The experimental activities were conducted on a prototype single cylinder research engine which has a modern combustion system design derived from a E5 compliant four cylinder engine which represents the state of the art of light duty diesel engine technology. The engine out exhaust gases for pollutant and particle analysis were diluted with a ratio of about 8.5 , in order to avoid the gas condensation, and sampled at the same point, upstream the typical after treatment systems (DOC and DPF). From the same point the exhaust gases were draw off and collected on a filter. The counting and sizing of particles was performed by means of a DMS (DMS 500, Cambustion, Cambridge, United Kingdom) which measurement principle is based on a deflection of electrically charged particles combined with electrical counting. The DMS 500 uses two internal dilution systems automatically controlled. The first stage was settled at 5:1 while the second one at 200:1, for a total dilution ratio of about 1000:1. The measurement range is from 5 to $1000 \mathrm{~nm}$ [61]. The BS soot originated from a D2876 CR engine, operated at 30\% load, extra-low rail pressure, and air throttling (blackening number 5), (see Additional file 1 for details).

\section{Test methodology}

The test procedure and points were chosen in order to provide additional experimental information on soot characteristics. The operating points were performed using E4 and E5 engine calibration (derived from the real fourcylinder engine of equal unit displacement) to ensure the value for practical application in the field of light duty engines. The tests were performed at fixed engine speed (2000 rpm) and load (5 bar brake mean effective pressure). Exhaust gas recirculation rates were set in order to reach the $\mathrm{E} 5$ low $\mathrm{NO}_{\mathrm{x}}$ emissions (26\% for E5 and 23\% for E4, respectively). Engine conditions were kept equal to the reference E4/5 calibration in both the two test series. A commercial European diesel was used as fuel.

\section{Soot sampling and pre-treatment}

Total particulate was collected from the exhaust pipe by isokinetic sampling. The sampling line comprised a Teflon filter (pore diameter $0.45 \mu \mathrm{m}$, Millipore Corporation, Bradford, MA, USA) placed in a temperature controlled system $(360 \mathrm{~K})$ to avoid steam condensation. The solid particulate collected on the filter was washed with dichloromethane (DCM) in order to remove condensable species and fuel residuals (soluble organic fraction, SOF). All non-covalently bound molecules (unburned and partially burned fuel, lube oil, PAH), about 15 wt.\%, adsorbed on soot surface have been removed by DCM washings. The complete removal of the non-covalently bound molecules was confirmed by infrared spectroscopy (absence of the signals in the wavelength range typical of aliphatic groups) and fluorescence spectroscopy (absence of any detectable fluorescence signal in the DCM after repeated washings). The carbonaceous solid after DCM extraction (soot) was dried, weighted and characterized.

\section{Soot characterization}

The full chemical-physical characterization of the soot has been performed after washing with DCM in order to probe the soot surface without the interference of physisorbed species (unburned hydrocarbons and tar species). Fourier transform infrared (FTIR) spectra were recorded on a Nicolet iS10 spectrometer (Thermo Fisher Scientific, Rockford, IL, USA) using the attenuated total reflectance (ATR) method. The hydrodynamic diameter of the carbonaceous materials was measured by using a Malvern Zetasizer Nano ZS instrument (Malvern Instruments Ltd, Malvern, United Kingdom) on soot suspension in Nmethylpyrrolidinone (NMP) [62]. TEM and HRTEM imaging were performed on a FEI Tecnai G2 F20 transmission electron microscope equipped with a field-emission gun (Fei Munich, Gräfelfing, Germany) [34]. Electronic structure measurements were performed using electron energy-loss spectroscopy (EELS).

Ash content was evaluated by TGA performed on a Perkin-Elmer Pyris 1 Thermogravimetric Analyzer in oxidative environment (air, $30 \mathrm{~mL}$ min-1). Soot samples were heated from $30^{\circ} \mathrm{C}$ up to $750^{\circ} \mathrm{C}$ at a rate of $10^{\circ} \mathrm{C}$ min- 1 . $\mathrm{UV}$-vis spectra of soot, suspended in NMP, were acquired on a HP 8453 Diode Array spectrophotometer (Agilent Technologies, Santa Clara, CA, USA). For the in vitro studies, the E4 and E5 soots were sterilized by heating at $180^{\circ} \mathrm{C}$. Both E4 and E5 soots contained $<0.00025 \mathrm{ng}$ of endotoxin/ $\mu \mathrm{g}$ of DEP, as determined by the quantitative chromogenic Limulus amebocyte lysate test (QCL-1000; BioWhittaker, Walkersville, MD, USA). Then the particles were washed three times in distilled water, suspended in phosphate-buffered saline at a stock concentration of $1 \mathrm{mg} / \mathrm{ml}$ and sonicated in a water bath at low intensity for $48 \mathrm{~h}$ before the use, in order to obtain a better dispersion of the particles that tend to agglomerate.

\section{Cell purification and culture}

Blood samples were obtained from 15 healthy donors (age range, 24-62 years; 7 males and 8 females). Informed consent was obtained from each study participant and the study was approved by the Ethical Committee of "Istituti 
Fisioterapici Ospedalieri-IFO", Rome, Italy. All subjects were lifetime nonsmokers and had no history of allergic diseases or chronic respiratory conditions. Peripheral blood mononuclear cells (PBMC) were isolated by Ficoll-Hypaque density-gradient centrifugation. Cells were cultured in RPMI-1640 medium (GIBCO BRL, Grand Island, NY, USA) supplemented with $10 \%$ fetal bovine serum (Euroclone, Pero, Milan, Italy), $2 \mathrm{mM}$ glutamine (Sigma, St. Louis, MO, USA) and $50 \mu \mathrm{g} / \mathrm{ml}$ gentamycin (Sigma). Preliminary dose response $(0.15,1.5,15,30$, and $60 \mu \mathrm{g} / \mathrm{ml})$ and time course (24, 48 and $72 \mathrm{~h}$ and 6 and 9 days) experiments showed that both E4 and E5 particles should be used at a dose of $30 \mu \mathrm{g} / \mathrm{ml}$ and at $24 \mathrm{~h}-72 \mathrm{~h}$ of culture (depending on the studied parameters) to obtain the highest detectable changes (see Additional file 1: Figure S1). Where indicated, cells were treated in the presence of lysosomal inhibitors E64d and PepA (both at $10 \mu \mathrm{g} / \mathrm{ml}$; Sigma) for the last $2 \mathrm{~h}$ of culture. For $\mathrm{T}$ cell proliferation, PBMC were stimulated with coated anti-CD3 mAb (clone UCHT1, $1.25 \mu \mathrm{g} / \mathrm{ml}$ and $2.5 \mu \mathrm{g} / \mathrm{ml}, \mathrm{R} \& \mathrm{D}$ Systems, Minneapolis, MN, USA) for $72 \mathrm{~h}$. Separation of untouched T cells from PBMC was performed by immunomagnetic-based depletion of non $\mathrm{T}$ cells using the Pan T Cell isolation Kit II (Miltenyi Biotec, Bergisch-Gladbach, Germany). Purity of isolated cells, assessed by flow cytometer, reached routinely at least $97 \%$.

\section{Transmission electron microscopy (TEM)}

For TEM examination, purified $\mathrm{T}$ cells were fixed in $2.5 \%$ cacodylate-buffered $(0.2 \mathrm{M}, \mathrm{pH} 7.2)$ glutaraldehyde for $20 \mathrm{~min}$ at room temperature and postfixed in $1 \%$ $\mathrm{OsO}_{4}$ in cacodylate buffer for $1 \mathrm{~h}$ at room temperature. Fixed specimens were dehydrated through a graded series of ethanol solutions and embedded in Agar 100 (Agar Aids, Cambridge, UK). Serial ultrathin sections were collected on 200-mesh grids and then counterstained with uranyl acetate and lead citrate. Sections were observed with a Philips 208 electron microscope at $80 \mathrm{kV}$.

\section{Flow cytometry}

\section{Surface and intracellular phenotyping}

Surface and intracellular phenotyping of PBMC was performed with combinations of mAbs fluorescein isothiocyanate (FITC), phycoerythrin (PE), peridinin chlorophyll protein (PerCP), or allophycocyanin (APC) as described before [63]. For surface staining, conjugated mAbs against human CD3, CD4, CD8, CD25, CD95, HLA-DR, CD69, and control mouse IgG1 (all from BD Biosciences, San Jose, CA, USA) were used. Analysis of cytokine production at the single cell level was performed as previously described with minor changes [63]. Briefly, untreated or DEP-treated PBMC were stimulated as follows: i) for IFN- $\gamma$, IL-2, and IL-4 analysis, $25 \mathrm{ng} / \mathrm{ml}$ phorbol myristate acetate (PMA, Sigma) and $1 \mu \mathrm{g} / \mathrm{ml}$ ionomycin
(Sigma) for the last $16 \mathrm{~h}$ of culture; ii) for IL-17 analysis, $50 \mathrm{ng} / \mathrm{ml}$ PMA (Sigma) and $1 \mu \mathrm{g} / \mathrm{ml}$ ionomycin (Sigma) for the last $4 \mathrm{~h}$ of culture; iii) for IL-10, $2.5 \mu \mathrm{g} / \mathrm{ml}$ phytohemagglutinin (Sigma) for the last $16 \mathrm{~h}$ of culture. To inhibit cytokine secretion, $10 \mu \mathrm{g} / \mathrm{ml}$ brefeldin A (Sigma) was added to each condition at the beginning of stimulation. Cells were either fixed with $4 \%$ paraformaldehyde (PFA) and permeabilized with FACS permeabilizing solution (BD Biosciences) for IFN- $\gamma$, IL-2, IL-4, and IL-10 detection or fixed and permeabilized with intracellular fixation and permeabilization buffer (eBioscience, San Diego, CA, USA) for IL-17 detection. The following cytokinespecific mAbs were used: FITC-labeled anti-IFN- $\gamma$, FITClabeled anti-IL-2, PE-labeled anti-IL-4, PE-labeled anti-IL-10 (all from BD Biosciences) and FITC-labeled anti-IL-17A (eBioscience). Surface phenotyping was performed with antiCD4 APC and anti-CD8 PerCP mAbs (BD Biosciences). Appropriate isotypic negative controls were run in parallel. To determine the frequency of $\mathrm{T}$ cell subsets, total lymphocytes were first gated by forward and side scatter and then additionally gated for CD4 or CD8 molecule expression.

\section{Apoptosis, $\Delta \Psi_{m}$, and proliferation}

Apoptosis was quantified using a FITC-conjugated AV and PI apoptosis detection kit according to the manufacturer's protocol (Marine Biological Laboratory, Woods Hole, MA, USA). $\triangle \Psi \mathrm{m}$ was studied by using the lipophilic cationic probe JC-1 (Invitrogen, Carlsbad, CA, USA), as previously described [64]. JC-1 is a metachromatic probe able to enter selectively the mitochondria. It exists in a monomeric form (in the green channel) but, depending on the membrane potential, JC-1 can form aggregates that are associated with a large shift in the emission range (in the orange channel) [65]. JC-1 was dissolved and stored according to the manufacturer's instructions. In brief, cells were incubated in complete medium for $15 \mathrm{~min}$ at $37^{\circ} \mathrm{C}$ in the dark with $10 \mu \mathrm{g} / \mathrm{ml} \mathrm{JC-1}$ probe. At the end of incubation period cells were analyzed on a flow cytometer. Proliferation was evaluated by measuring the Ki-67 nuclear Ag expression using the PE-mouse anti-human Ki-67 Set according to the manufacturer's protocol (BD Biosciences).

Acquisition was performed on a FACSCalibur cytometer (BD Biosciences) and 30.000-50.000 events per sample were run. Data were analyzed using the Cell Quest Pro software (BD Biosciences).

\section{Sodium dodecyl sulfate polyacrylamide gel electrophoresis (SDS-PAGE) and Western blot}

Purified T lymphocytes were lysed in RIPA buffer (100 mM Tris- $\mathrm{HCl} \mathrm{pH}$ 8, $150 \mathrm{mM} \mathrm{NaCl}, 1 \%$ Triton X-100, $1 \mathrm{mM}$ $\mathrm{MgCl}_{2}$ ) in the presence of a complete protease inhibitor mixture (Roche Diagnostics GmbH, Mannheim, Germany). Protein content was determined by the Bradford assay (Bio-Rad Laboratories, Richmond, CA, USA). The samples 
were loaded onto SDS-PAGE and, after electrophoresis, proteins were transferred onto nitrocellulose membrane (GE Healthcare, Munich, Germany) by means of a TransBlot transfer cell (Bio-Rad Laboratories). The membranes were then blocked in 5\% nonfat milk for $1 \mathrm{~h}$ at room temperature and incubated with the appropriate antibody in Tris-buffered saline (TBS) containing $0.1 \%$ Tween 20 and $5 \%$ bovine serum albumin or nonfat milk. Regarding SNCA detection, because SNCA monomers tend to easily detach from blotted membranes, resulting in no or very poor detection, after Western blot, nitrocellulose membrane was fixed by incubation for 30 min with TBS containing 0.4\% PFA [66]. Rabbit anti-human LC3 (Cell Signaling Technology, Beverly, MA, USA), rabbit anti-human SQSTM1/p62, (Sigma), rabbit anti-human NBR1 (Cell Signaling Technology), and mouse anti-human SNCA (clone syn211, Sigma) were used as primary antibodies. Peroxidase-conjugated goat anti-rabbit IgG (Bio-Rad Laboratories) or anti-mouse IgG (Bio-Rad Laboratories) were used as secondary antibodies and the reactions were developed using the ECL Prime Western Blotting Detection Reagent (GE Healthcare). To ensure the presence of equal amounts of proteins, the membranes were reprobed with a rabbit anti-human $\beta$-actin antibody (Sigma). Quantification of protein expression was performed by densitometry analysis of the autoradiograms (GS-700 Imaging Densitometer, Bio-Rad Laboratories).

\section{Determination of ATP}

An equal number of T lymphocytes $\left(2 \times 10^{5}\right)$ per condition was lysed (10 mM Tris pH 7.5, $0.1 \mathrm{M} \mathrm{NaCl}, 1 \mathrm{mM}$ EDTA, 1\% Triton X-100) and ATP production was determined by using a luminescent ATP detection assay kit (Invitrogen) according to the manufacturer's instructions. A Packard TopCount Microplate Scintillation and Luminescence Counter was used as detection instrument (Packard Instrument Company, Wellesley, MA, USA) and values were calculated based on an ATP standard curve.

\section{Statistical analysis}

Data were analysed using GraphPad Prism v5 (GraphPad Inc., San Diego, CA, USA). The Mann-Whitney unpaired test was used to compare quantitative variables in different treatment groups. $\mathrm{p}$ values $<0.05$ were considered as significant.

\section{Additional file}

Additional file 1: Supporting information.

\section{Abbreviations}

APC: Allophycocyanin; ATP: Adenosine triphosphate; AV: Annexin V; BS: Black soot; DCM: Dichloromethane; DEP: Diesel exhaust particles; DLS: Dynamic light scattering; DMS: Differential mobility spectrometer; DOC: Diesel oxidation catalyst; DPF: Diesel particulate filter; $\Delta \psi_{\mathrm{m}}$ : Mitochondrial membrane potential; E4: Euro 4; E5: Euro 5; FITC: Fluorescein isothiocyanate; HRTEM: High resolution transmission electron microscopy; IFN- $\gamma$ : Interferon $\gamma$; IL: Interleukin; JC-1: 5,5',6,6'-tetrachloro-1,1',3,3'-tetraethylbenzimidazol carbocyanine iodide; LC3: Microtubule-associated protein 1 light chain 3; mAb: Monoclonal antibody; NBR1: Neighbor of BRCA1 gene 1; NMP: N-methylpyrrolidinone; PBMC: Peripheral blood mononuclear cells; PAH: Polycyclic aromatic hydrocarbons; PE: Phycoerythrin; PepA: Pepstatin A; PerCP: Peridinin chlorophyll protein; PFA: Paraformaldehyde; PI: Propidium iodide; PMA: Phorbol myristate acetate; SDS-PAGE: Sodium dodecyl sulfate polyacrylamide gel electrophoresis; SNCA: a-synuclein; SQSTM1: Sequestosome 1; TBS: Tris-buffered saline; TEM: Transmission electron microscopy;

TGA: Termogravimetric analysis.

\section{Competing interests}

The authors declare that they have no competing interests.

\section{Authors' contributions}

MP conceived the study, designed experiments, analyzed data and wrote the manuscript. AM carried out cellular and molecular studies and analyzed data. SC participated in molecular studies. AT performed transmission electron microscopy. AM performed biological sample collection and preparation. MA, VG, CB and GDB performed DEP collection and characterization and helped to draft the manuscript. GC performed imaging analysis. EO analyzed data, helped to draft the manuscript and provided intellectual input. AG participated in sample collection, helped to draft the manuscript and provided intellectual input. SF conceived the study, supervised work, wrote the manuscript and provided intellectual input throughout the study. All authors read and approved the final manuscript.

\section{Authors' information}

Antonello Giovannetti and Silvana Fiorito To be considered as senior authors.

\section{Author details}

${ }^{1}$ Department of Cell Biology and Neurosciences, Istituto Superiore di Sanità, Rome, Italy. ${ }^{2}$ Department of Technology and Health, Istituto Superiore di Sanità, Rome, Italy. ${ }^{3}$ San Gallicano Dermatologic Institute, IRCCS-IFO, Laboratory of Cutaneous Physiopathology and Integrated Center of Metabolomics Research, Rome, Italy. ${ }^{4}$ Istituto di Ricerche sulla Combustione (IRC), CNR- Naples, Italy. ${ }^{5}$ Istituto Motori (IM), CNR-Naples, Italy. ${ }^{6}$ Istituto San Raffaele Sulmona, Sulmona, Italy. ${ }^{7}$ Department of Clinical Medicine, Division of Clinical Immunology, Sapienza University of Rome, Rome, Italy. ${ }^{8}$ Institute of Translational Pharmacology, CNR-Rome, Italy. ${ }^{9}$ Research Center for Nanotechnologies applied to Engineering-CNIS, Rome, Italy.

Received: 20 June 2014 Accepted: 3 December 2014

Published online: 14 December 2014

\section{References}

1. Donaldson K, Poland CA: Inhaled nanoparticles and lung cancer - what we can learn from conventional particle toxicology. Swiss Med Wkly 2012, 142:w13547.

2. Donaldson $K$, Seaton A: A short history of the toxicology of inhaled particles. Part Fibre Toxicol 2012, 9:13.

3. Kelly FJ, Fussell JC: Air pollution and airway disease. Clin Exp Allergy 2011, 41:1059-1071.

4. Shah AS, Langrish JP, Nair H, McAllister DA, Hunter AL, Donaldson K, Newby DE, Mills NL: Global association of air pollution and heart failure: a systematic review and meta-analysis. Lancet 2013, 382:1039-1048.

5. Nemmar A, Hoet PH, Vanquickenborne B, Dinsdale D, Thomeer $M$, Hoylaerts MF, Vanbilloen H, Mortelmans L, Nemery B: Passage of inhaled particles into the blood circulation in humans. Circulation 2002, 105:411-414.

6. Wichmann HE: Diesel exhaust particles. Inhal Toxicol 2007, 19(Suppl 1):241-244.

7. Kreyling WG, Semmler-Behnke M, Seitz J, Scymczak W, Wenk A, Mayer P, Takenaka S, Oberdorster G: Size dependence of the translocation of inhaled iridium and carbon nanoparticle aggregates from the lung of rats to the blood and secondary target organs. Inhal Toxicol 2009, 21(Suppl 1):55-60.

8. Oberdorster G, Sharp Z, Atudorei V, Elder A, Gelein R, Lunts A, Kreyling W, Cox C: Extrapulmonary translocation of ultrafine carbon particles following whole-body inhalation exposure of rats. J Toxicol Environ Health A 2002, 65:1531-1543. 
9. Oberdorster G: Safety assessment for nanotechnology and nanomedicine: concepts of nanotoxicology. J Intern Med 2010, 267:89-105.

10. Mills NL, Amin N, Robinson SD, Anand A, Davies J, Patel D, de la Fuente JM, Cassee FR, Boon NA, Macnee W, Millar AM, Donaldson K, Newby DE: Do inhaled carbon nanoparticles translocate directly into the circulation in humans? Am J Respir Crit Care Med 2006, 173:426-431.

11. Ema M, Naya M, Horimoto M, Kato H: Developmental toxicity of diesel exhaust: a review of studies in experimental animals. Reprod Toxicol 2013, 42:1-17.

12. Nel AE, Diaz-Sanchez D, Ng D, Hiura T, Saxon A: Enhancement of allergic inflammation by the interaction between diesel exhaust particles and the immune system. J Allergy Clin Immunol 1998, 102:539-554.

13. Diaz-Sanchez D, Garcia MP, Wang M, Jyrala M, Saxon A: Nasal challenge with diesel exhaust particles can induce sensitization to a neoallergen in the human mucosa. J Allergy Clin Immunol 1999, 104:1183-1188.

14. Diaz-Sanchez D, Tsien A, Casillas A, Dotson AR, Saxon A: Enhanced nasal cytokine production in human beings after in vivo challenge with diesel exhaust particles. J Allergy Clin Immunol 1996, 98:114-123.

15. Diaz-Sanchez D, Tsien A, Fleming J, Saxon A: Combined diesel exhaust particulate and ragweed allergen challenge markedly enhances human in vivo nasal ragweed-specific IgE and skews cytokine production to a $T$ helper cell 2-type pattern. J Immunol 1997, 158:2406-2413.

16. Finkelman FD, Yang M, Orekhova T, Clyne E, Bernstein J, Whitekus M, Diaz-Sanchez D, Morris SC: Diesel exhaust particles suppress in vivo IFN-gamma production by inhibiting cytokine effects on NK and NKT cells. J Immunol 2004, 172:3808-3813.

17. Fujieda S, Diaz-Sanchez D, Saxon A: Combined nasal challenge with diesel exhaust particles and allergen induces In vivo lgE isotype switching. Am J Respir Cell Mol Biol 1998, 19:507-512.

18. Inoue $\mathrm{K}$, Takano $\mathrm{H}$ : Biology of diesel exhaust effects on allergic pulmonary inflammation. Yakugaku Zasshi 2011, 131:367-371.

19. Mamessier E, Nieves A, Vervloet D, Magnan A: Diesel exhaust particles enhance T-cell activation in severe asthmatics. Allergy 2006, 61:581-588.

20. Nilsen AM, Hagemann R, Eikas H, Egeberg K, Norkov T, Sundan A: Reduction of IL-12 p40 production in activated monocytes after exposure to diesel exhaust particles. Int Arch Allergy Immunol 2003, 131:201-208.

21. Ohtani T, Nakagawa S, Kurosawa M, Mizuashi M, Ozawa M, Aiba S: Cellular basis of the role of diesel exhaust particles in inducing Th2-dominant response. J Immunol 2005, 174:2412-2419.

22. Sasaki Y, Ohtani T, Ito Y, Mizuashi M, Nakagawa S, Furukawa T, Horii A, Aiba S: Molecular events in human T cells treated with diesel exhaust particles or formaldehyde that underlie their diminished interferon-gamma and interleukin-10 production. Int Arch Allergy Immunol 2009, 148:239-250.

23. Takenaka H, Zhang K, Diaz-Sanchez D, Tsien A, Saxon A: Enhanced human $\mathrm{IgE}$ production results from exposure to the aromatic hydrocarbons from diesel exhaust: direct effects on B-cell IgE production. J Allergy Clin Immunol 1995, 95:103-115.

24. Tsien A, Diaz-Sanchez D, Ma J, Saxon A: The organic component of diesel exhaust particles and phenanthrene, a major polyaromatic hydrocarbon constituent, enhances IgE production by lgE-secreting EBV-transformed human B cells in vitro. Toxicol Appl Pharmacol 1997, 142:256-263.

25. Vattanasit U, Navasumrit P, Khadka MB, Kanitwithayanun J, Promvijit J, Autrup $\mathrm{H}$, Ruchirawat M: Oxidative DNA damage and inflammatory responses in cultured human cells and in humans exposed to traffic-related particles. Int J Hyg Environ Health 2014, 217:23-33.

26. Klionsky DJ: Autophagy: from phenomenology to molecular understanding in less than a decade. Nat Rev Mol Cell Biol 2007, 8:931-937.

27. Giovannetti A, Pierdominici M, Di lorio A, Cianci R, Murdaca G, Puppo F Pandolfi F, Paganelli R: Apoptosis in the homeostasis of the immune system and in human immune mediated diseases. Curr Pharm Des 2008, 14:253-268.

28. McLeod IX, Jia W, He YW: The contribution of autophagy to lymphocyte survival and homeostasis. Immunol Rev 2012, 249:195-204.

29. Pierdominici M, Vomero M, Barbati C, Colasanti T, Maselli A, Vacirca D, Giovannetti A, Malorni W, Ortona E: Role of autophagy in immunity and autoimmunity, with a special focus on systemic lupus erythematosus. FASEB J 2012, 26:1400-1412.

30. Pua HH, He YW: Maintaining T lymphocyte homeostasis: another duty of autophagy. Autophagy 2007, 3:266-267.

31. Walsh CM, Edinger AL: The complex interplay between autophagy, apoptosis, and necrotic signals promotes T-cell homeostasis. Immunol Rev 2010, 236:95-109.
32. Fiorito S, Mastrofrancesco A, Cardinali G, Rosato E, Salsano F, Su DS, Serafino A, Picardi M: Effects of carbonaceous nanoparticles from low-emission and older diesel engines on human skin cells. Carbon 2011, 49:5038-5048.

33. Su DS, Serafino A, Muller JO, Jentoft RE, Schlogl R, Fiorito S: Cytotoxicity and inflammatory potential of soot particles of low-emission diesel engines. Environ Sci Technol 2008, 42:1761-1765.

34. Mastrofrancesco A, Alfè M, Rosato E, Gargiulo V, Beatrice C, Di Blasio G, Zhang B, Su DS, Picardi M, Fiorito S: Pro-inflammatory effects of diesel exhaust nanoparticles on Scleroderma skin cells. J Immunol Res 2014, 2014:138751.

35. Arnal C, Alfè M, Gargiulo V, Ciajolo A, Alzueta MU, Millera A, Bilbao R: Characterization of Soot. In Cleaner Combustion. Developing Detailed Chemical Kinetic Models. Edited by Battin-Leclerc F, Simmie JM, Blurock E. London: Springer-Verlag; 2013:333-361.

36. Alfè $M$, Apicella B, Barbella R, Rouzaud JN, Tregrossi A, Ciajolo A: Structure-property relationship in nanostructures of young and mature soot in premixed flames. Proc Combust Inst 2009, 32:697-704

37. Colasanti T, Vomero M, Alessandri C, Barbati C, Maselli A, Camperio C, Conti F, Tinari A, Carlo-Stella C, Tuosto L, Benincasa D, Valesini G, Malorni W, Pierdominici M, Ortona E: Role of alpha-synuclein in autophagy modulation of primary human T lymphocytes. Cell Death Dis 2014, 5:e1265.

38. Klionsky DJ, Abdalla FC, Abeliovich H, Abraham RT, Acevedo-Arozena A, Adeli K, Agholme L, Agnello M, Agostinis P, Aguirre-Ghiso JA, Ahn HJ, Ait-Mohamed O, Ait-Si-Ali S, Akematsu T, Akira S, Al-Younes HM, Al-Zeer MA, Albert ML, Albin RL, Alegre-Abarrategui J, Aleo MF, Alirezaei M, Almasan A, Almonte-Becerril M, Amano A, Amaravadi R, Amarnath S, Amer AO,

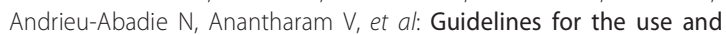
interpretation of assays for monitoring autophagy. Autophagy 2012, 8:445-544.

39. Tanida I, Ueno T, Kominami E: LC3 conjugation system in mammalian autophagy. Int J Biochem Cell Biol 2004, 36:2503-2518.

40. Skulachev VP: Mitochondrial physiology and pathology; concepts of programmed death of organelles, cells and organisms. Mol Aspects Med 1999, 20:139-184.

41. Kroemer G, Reed JC: Mitochondrial control of cell death. Nat Med 2000, 6:513-519

42. Liati A, Eggenschwiler PD, Schreiber D, Zelenay V, Ammann M: Variations in diesel soot reactivity along the exhaust after-treatment system, based on the morphology and nanostructure of primary soot particles. Combustion Flame 2013, 160:671-681.

43. Stern ST, Adiseshaiah PP, Crist RM: Autophagy and lysosomal dysfunction as emerging mechanisms of nanomaterial toxicity. Part Fibre Toxicol 2012, 9:20.

44. Chaudhuri N, Jary H, Lea S, Khan N, Piddock KC, Dockrell DH, Donaldson K, Duffin R, Singh D, Parker LC, Sabroe I: Diesel exhaust particle exposure in vitro alters monocyte differentiation and function. PLOS One 2012, 7:e51107.

45. Choi AM, Ryter SW, Levine B: Autophagy in human health and disease. N Engl J Med 2013, 368:651-662.

46. Deretic V: Autophagy in immunity and cell-autonomous defense against intracellular microbes. Immunol Rev 2011, 240:92-104.

47. Munz C: Antigen processing via autophagy-not only for MHC class II presentation anymore? Curr Opin Immunol 2010, 22:89-93.

48. White E: Deconvoluting the context-dependent role for autophagy in cancer. Nat Rev Cancer 2012, 12:401-410.

49. Pierdominici M, Barbati C, Vomero M, Locatelli SL, Carlo-Stella C, Ortona E, Malorni W: Autophagy as a pathogenic mechanism and drug target in lymphoproliferative disorders. FASEB J 2014, 28:524-535.

50. Alessandri C, Barbati C, Vacirca D, Piscopo P, Confaloni A, Sanchez M, Maselli A, Colasanti T, Conti F, Truglia S, Perl A, Valesini G, Malorni W, Ortona E, Pierdominici M: T lymphocytes from patients with systemic lupus erythematosus are resistant to induction of autophagy. FASEB J 2012, 26:4722-4732

51. Hiura TS, Li N, Kaplan R, Horwitz M, Seagrave JC, Nel AE: The role of a mitochondrial pathway in the induction of apoptosis by chemicals extracted from diesel exhaust particles. J Immunol 2000, 165:2703-2711.

52. Wang XZ, Yang Y, Li R, McGuinnes C, Adamson J, Megson IL, Donaldson K: Principal component and causal analysis of structural and acute in vitro toxicity data for nanoparticles. Nanotoxicology 2014, 8:465-476.

53. Xia T, Korge P, Weiss JN, Li N, Venkatesen MI, Sioutas C, Nel A: Quinones and aromatic chemical compounds in particulate matter induce 
mitochondrial dysfunction: implications for ultrafine particle toxicity. Environ Health Perspect 2004, 112:1347-1358.

54. Zamzami N, Marchetti P, Castedo M, Zanin C, Vayssiere UL, Petit PX, Kroemer G: Reduction in mitochondrial potential constitutes an early irreversible step of programmed lymphocyte death in vivo. J Exp Med 1995, 181:1661-1672.

55. Ling X, He Y, Zhang G, Zhou Y, Yan B: Increased P-glycoprotein expression in mitochondria is related to acquired multidrug resistance in human hepatoma cells depleted of mitochondrial DNA. Int J Oncol 2012, 40:109-118.

56. Lambrecht BN, Hammad H: Asthma: the importance of dysregulated barrier immunity. Eur J Immunol 2013, 43:3125-3137.

57. Smith KA: Interleukin-2: inception, impact, and implications. Science 1988 , 240:1169-1176.

58. Furtado GC, Curotto de Lafaille MA, Kutchukhidze N, Lafaille Jj: Interleukin 2 signaling is required for $\mathrm{CD} 4(+)$ regulatory T cell function. J Exp Med 2002, 196:851-857.

59. Refaeli $Y$, Van Parijs L, London CA, Tschopp J, Abbas AK: Biochemical mechanisms of IL-2-regulated Fas-mediated T cell apoptosis. Immunity 1998, 8:615-623.

60. Muller L, Chehrazi CV, Henderson MW, Noah TL, Jaspers I: Diesel exhaust particles modify natural killer cell function and cytokine release. Part Fibre Toxicol 2013, 10:16.

61. Di Blasio G, Beatrice C, Molina S: Effect of port injected ethanol on combustion characteristics in a dual-fuel light duty diesel engine SAE technical paper series. In Proceedings SAE 2013 World Congress \& Exibition: 16-18 April 2013; Detroit. Michigan: SAE Technical Paper 2013-01-1692; 2013.

62. Muller JO, Su DS, Wild U, Schlogol R: Bulk and surface structural investigations of diesel engine soot and carbon black. Phys Chem Chem Phys 2007, 9:4018-4025.

63. Giovannetti A, Pierdominici M, Mazzetta F, Marziali M, Renzi C, Mileo AM, De Felice M, Mora B, Esposito A, Carello R, Pizzuti A, Paggi MG, Paganelli R, Malorni W, Aiuti F: Unravelling the complexity of T cell abnormalities in common variable immunodeficiency. J Immunol 2007, 178:3932-3943.

64. Pierdominici M, Giammarioli AM, Gambardella L, De Felice M, Quinti I, lacobini M, Carbonari M, Malorni W, Giovannetti A: Pyrimethamine (2,4-diamino-5-p-chlorophenyl-6-ethylpyrimidine) induces apoptosis of freshly isolated human T lymphocytes, bypassing CD95/Fas molecule but involving its intrinsic pathway. J Pharmacol Exp Ther 2005, 315:1046-1057.

65. Cossarizza A, Franceschi C, Monti D, Salvioli S, Bellesia E, Rivabene R, Biondo L, Rainaldi G, Tinari A, Malorni W: Protective effect of N-acetylcysteine in tumor necrosis factor-alpha-induced apoptosis in U937 cells: the role of mitochondria. Exp Cell Res 1995, 220:232-240.

66. Lee BR, Kamitani T: Improved immunodetection of endogenous alpha-synuclein. PLoS One 2011, 6:e23939.

doi:10.1186/s12989-014-0074-0

Cite this article as: Pierdominici et al:: Diesel exhaust particle exposure

in vitro impacts T lymphocyte phenotype and function. Particle and Fibre Toxicology 2014 11:74.

\section{Submit your next manuscript to BioMed Central and take full advantage of:}

- Convenient online submission

- Thorough peer review

- No space constraints or color figure charges

- Immediate publication on acceptance

- Inclusion in PubMed, CAS, Scopus and Google Scholar

- Research which is freely available for redistribution 